\title{
DINAMIKA DAN IMPLEMENTASI HUKUM ORGANISASI PERUSAHAAN DALAM SISTEM HUKUM INDONESIA
}

\author{
Muhibbuthabary \\ Fakultas Syari'ah dan Hukum UIN Ar-Raniry Aceh \\ E-Mail:muhib_net@yahoo.com
}

\begin{abstract}
The legal system in Indonesia explained that the act of commerce is the act of purchasing goods for resale. While the organization is a coordination unit comprising at least two people, has a function to achieve a certain goal or set of tools. the company is a unit of business organizations that produce goods and services to meet the needs of the community with the aim of the company is a unit of business organizations that produce goods and services to meet the needs of the community with the aim to obtain profit. The company is a business organization that has carried out business activities and continuous, uninterrupted and overt move out with the aim to get benefit. In the Code of Commercial Law mentioned that perbu-atan commerce on the organization of the company is the act of purchase does not include sales deeds, because sales is part of the aim of business. In practice, the legal system of Indonesia has set about permit the establishment and governance of enterprise organizations are legal entities such as limited liability, Firma, cooperatives, foundations, enterprises, and etc. This has been stipulated in the legislation, namely Law Number 3 of 1992 about the Registration Company and Law Number 8 of 1997 concerning Company Documents.
\end{abstract}

\begin{abstract}
Abstrak
Sistem hukum di Indonesia menjelaskan bahwa perbuatan perniagaan adalah perbuatan pembelian barang-barang untuk dijual kembali. Sedangkan Organisasi adalah suatu unit terkoordinasi yang terdiri setidaknya dua orang, berfungsi mencapai suatu sasaran tertentu atau serangkaian sarana. Perusahaan adalah suatu unit organisasi usaha yang memproduksi barang dan jasa untuk memenuhi kebutuhan masyarakat dengan tujuan untuk medapatkan keuntungan. Adapun perusahaan adalah suatu organisasi bisnis yang memiliki kegiatan usaha dan dijalankan secara terus-menerus, tidak terputus-putus serta terang-terangan yang bergerak keluar dengan tujuan untuk mendapatkan berbagai keuntungan. Dalam Kitab Undang-Undang Hukum Dagang (KUHD) disebutkan bahwa perbuatan perniagaan pada organisasi perusahaan adalah perbuatan pembelian tidak termasuk perbuatan penjualan, karena penjualan merupakan tujuan pembelian itu. Dalam praktiknya, sistem hukum Indonesia telah mengatur tentang izin pendirian dan tata kelola organisasi perusahaan berbadan hukum seperti Perseoran Terbatas, Firma, Koperasi, Yayasan, BUMN, dan sebagainya. Hal ini telah diatur di dalam peraturan perundang-undangan, yaitu UndangUndang Nomor 3 Tahun 1992 tentang Wajib Daftar Perusahaan dan Undang-Undang Nomor 8 Tahun 1997 tentang Dokumen Perusahaan.
\end{abstract}

Kata Kunci:

Legal System, Business, Organization, Code, Commercial Law

\section{A. Pendahuluan}

Dewasa ini kemajuan dunia bisnis sudah sangat pesat, hal ini disebabkan oleh adanya kebutuhan masyarakat yang semakin meningkat baik berupa barang maupun jasa untuk keperluan sarana dan prasarana, sehing- 
ga mendorong masyarakat untuk melakukan kegiatan bisnis meskipun sebagian masyarakat masih memilih melakukan kegiatan bisnis secara mandiri dan sebagian lagi melakukan bisnis dengan membentuk suatu organisasi perusahaan sebagai wadahnya.

Kehadiran Undang-Undang Nomor 40 Tahun 2007 tentang Perseroan Terbatas menggantikan Undang-Undang Nomor 1 Tahun 1995 membawa perubahan signifikan pada "aspek hukum organisasi" dan aktifitas komersial suatu Perseroan Terbatas. Perusahaan dipandang dari sudut ekonomi adalah suatu unit organisasi usaha yang memproduksi barang dan jasa untuk memenuhi kebutuhan masyarakat dengan tujuan untuk mendapatkan keuntungan. Sedangkan perusahaan dipandang dari sisi hukum adalah suatu kegiatan usaha yang dijalankan secara terusmenerus, tidak terputus-putus dan terangterangan yang bergerak keluar dengan tujuan untuk mendapatkan berbagai keuntungan.

Perusahaan yang bergerak dibidang bisnis ada yang sudah berbadan hukum dan ada pula yang belum berbadan hukum. Perseroan Terbatas (PT), koperasi, persekutuan komanditer (CV) merupakan organisasi perusahaan yang berbadan hukum, sedangkan yayasan, firma, Usaha Dagang (UD), kongsi adalah oraganisasi perusahaan yang belum/tidak berbadan hukum. Oleh karena itu, makalah ini akan menyajikan pembahasan ringkas seputar penerapan sistem peraturan perundang-undangan hukum perusahaan di Indonesia.

\section{B. Organisasi Perusahaan dalam Sistem Hukum Indonesia}

Menurut Veithal dalam Riva'i menjelaskan bahwa organisasi adalah wadah yang memungkinkan masyarakat dapat meraih hasil yang sebelumnya tidak dapat dicapai oleh individu dan secara sendiri-sendiri. Organisasi suatu unit terkoordinasi yang terdiri setidaknya dua orang, berfungsi mencapai suatu sasaran tertentu atau serangkaian sarana.
Masih menurut Riva'i, organisasi adalah suatu bentuk kelompok individu-individu dengan struktur dan tujuan tertentu. ${ }^{1}$ Sedangkan Siagian menjelaskan bahwa pengorganisasian adalah Keseluruhan proses pengelompokan orang-orang, alat-alat, tugastugas, tanggung jawab, dan wewenang sedemikian rupa sehingga tercipta suatu organisasi yang dapat digerakkan sebagai suatu kesatuan dalam rangka pencapaian tujuan yang telah ditentukan. ${ }^{2}$

Dalam organisasi tersebut perlu adanya manusia, karena manusia adalah pendukung utama setiap organisasi apapun bentuk dari organisasi. Karena setiap perilaku manusia yang berada dalam suatu kelompok atau organisasi adalah awal dari perilaku manusia. Lebih lanjut Ndraha dalam Marihot Tua Efendi Harianja berpendapat bahwa organisasi sebagai living organism yang sudah ada, suatu organisasi merupakan output proses panjang dimasa lalu, sedangkan sebagai produk proses organizing, organisasi adalah alat atau input bagi usaha mencapai tujuan ke depan. Jadi, ada organsiasi sebagai output (OSO) dan ada organisasi sebagai input (OSI). Proses OSI-OSO-OSI merupakan sebuah siklus. Pada giliranya suatu OSI menjadi OSO, dan OSO yang mengalami regenerasi menjadi OSI baru, kalau tidak, mungkin mati. $^{3}$

Dewasa ini, organisasi merupakan salah satu bidang yang sangat berkembang. Jurusan-jurusan yang mengembangkan studi organisasi umumnya, adalah fakultasfakultas hukum, sekalipun demikian banyak pula perguruan tinggi yang memiliki program psikologi industri dan ekonomi industrial. Pengaruh bidang ini dalam dunia bisnis timbul sejalan dengan tulisan para praktisi hukum yang menerapkan penelitian akademis

1 Rivai, Kepemimpinan dan Perilaku Organisasi, (Jakarta: Raja Grafindo Persada, 2006), hlm. 189.

2 Sondang P. Siagian, Analisis serta Perumusan Kebijaksanaan dan Strategi Organisasi, (Jakarta: Haji Masagung, 1993), hlm. 95.

${ }_{3}^{3}$ Marihot Tua Efendi Harianja, Perilaku Organisasi (Memahami dan Mengelola Perilaku Dalam Organisasi, Bandung, UNPAR PRESS, 2006), hlm. 47. 
pada praktis bisnis. Perilaku organisasi menjadi penting dalam hukum ekonomi global mengingat keragaman asal-usul kebudayaan dan nilai dari para pekerja yang dituntut untuk secara bersama-sama bekerja secara efektif dan efisien.

Dalam tata hukum organisasi perusahaan di Indonesia dikenal beberapa istilah. Misalnya, Firma berasal dari bahasa Belanda venootschap onder firma; secara harfiah: perserikatan dagang antara beberapa perusahaan atau sering juga disebut Fa, adalah sebuah bentuk persekutuan untuk menjalankan usaha antara dua orang atau lebih dengan memakai nama bersama. Pemilik firma terdiri dari beberapa orang yang bersekutu dan masing-masing anggota persekutuan menyerahkan kekayaan pribadi sesuai yang tercantum dalam akta pendirian perusahaan.

Berdasarkan Pasal 16 Kitab UndangUndang Hukum Dagang (KUHD), Persekutuan Firma adalah persekutuan yang diadakan untuk menjalankan suatu perusahaan dengan memakai nama bersama. Menurut pendapat lain, Persekutuan Firma adalah setiap perusahaan yang didirikan untuk menjalankan suatu perusahaan di bawah nama bersama atau firma sebagai nama yang dipakai untuk berdagang bersama-sama. Persekutuan Firma merupakan bagian dari persekutuan perdata, maka dasar hukum persekutuan firma terdapat pada Pasal 16 sampai dengan Pasal 35 Kitab Undang-Undang Hukum Dagang (KUHD) dan pasal-pasal lainnya dalam Kitab Undang-Undang Hukum Perdata (KUH Perdata) yang terkait. Dalam Pasal 22 KUHD disebutkan bahwa persekutuan firma harus didirikan dengan akta otentik tanpa adanya kemungkinan untuk disangkalkan kepada pihak ketiga bila akta itu tidak ada. ${ }^{4}$

Pasal 23 KUHD dan Pasal 28 KUHD menyebutkan setelah akta pendirian dibuat, maka harus didaftarkan di Kepaniteraan Pengadilan Negeri di mana firma tersebut berkedudukan dan kemudian akta pendirian tersebut harus diumumkan dalam Berita Negara Republik Indonesia. Selama akta pen-

4 Lihat Pasal 16 dan Pasal 35 Kitab UndangUndang Hukum Dagang (KUHD). dirian belum didaftarkan dan diumumkan, maka pihak ketiga menganggap firma sebagai persekutuan umum yang menjalankan segala macam usaha, didirikan untuk jangka waktu yang tidak terbatas serta semua sekutu berwenang menandatangani berbagai surat untuk firma ini sebagaimana dimaksud di dalam Pasal 29 KUHD. Isi ikhtisar resmi akta pendirian firma dapat dilihat di Pasal 26 KUHD yang harus memuat sebagai berikut: ${ }^{5}$

1. Nama, nama kecil, pekerjaan dan tempat tinggal para sekutu firma;

2. Pernyataan firmanya dengan menunjukan apakah persekutuan itu umum ataukah terbatas pada suatu cabang khusus perusahaan tertentu dan dalam hal terakhir dengan menunjukan cabang khusus itu;

3. Penunjukan para sekutu yang tidak diperkenankan bertanda tangan atas nama firma;

4. Saat mulai berlakunya persekutuan dan saat berakhirnya; dan

5. Dan selanjutnya, pada umumnya bagianbagian dari perjanjiannya yang harus dipakai untuk menentukan hak-hak pihak ketiga terhadap para sekutu.

Pada umumnya Persekutuan firma disebut juga sebagai perusahaan yang tidak berbadan hukum karena firma telah memenuhi syarat/unsur materiil namun syarat/unsur formalnya berupa pengesahan atau pengakuan dari negara berupa peraturan perundangundangan belum ada. Hal inilah yang menyebabkan Persekutuan Firma bukan merupakan persekutuan yang berbadan hukum. Persekutuan firma dapat didirikan dengan cara membuat akta persetujuan sendiri atau persero (anggota persekutuan). Namun agar lebih formal, sebaiknya pendirian sebuah firma dilakukan di depan notaris.

Ciri organisasi perusahaan firma adalah: ${ }^{6}$

1. Para persero aktif dalam kegiatan bada usaha sesuai bidang tugasnya;

2. Tanggung jawab tidak terbatas dan di tanggung bersama (solider);

\footnotetext{
${ }^{5}$ Lihat Pasal 23 KUHD dan Pasal 28 KUHD.

6 Lihat penjelasan Joko Suryono, "Ciri-ciri Organisasi Perusahaan, artikel dalam http://www.trainingcenter.co.id/aspek-hukumorganisasi-perusahaan diakses tanggal 22 Januari 2014.
} 
3. Tidak berbadan hukum;

4. Seorang anggota mempunyai hak untuk membubarkan firma;

5. Pendiriannya tidak memerlukan akta pendirian; dan

6. Mudah memperoleh kredit usaha.

Keuntungan perseroan firma adalah se-

bagai berikut:

1. Pengelola usaha dapat di lakukan sesuai bidang keahlian masing-masing, sehingga kemampuan manajemen lebih besar karena adanya pembagian kerja;

2. Risiko ditanggung bersama;

3. Kelancaran usaha mendapatkan kredit;

4. Tergabung alasan-alasan rasional;

5. Perhatian sekutu yang sungguh-sungguh pada perusahaan; dan

6. Prosedur pendirian relative mudah. Kerugian perseroan firma adalah sebagai berikut:

1. Tiap persero harus bertanggung jawab atas perbuatan persero lainnya, sehingga apabila ada tindakan tidak sesuai dengan prosedur dari salah seorang persero, maka persero lainnya harus ikut bertanggungjawab;

2. Seringkali timbul perselisihan di antara para persero dalam hal pengambilan kebijaksanaan;

3. Utang usaha perusahaan ditanggung oleh kekayaan pribadi para anggota firma; dan

4. Kelangsungan hidup perusahaan tidak terjamin, sebab bila salah seorang anggota keluar, maka firma pun bubar.

Ketentuan ini berlaku baik bagi persekutuan firma yang berbeda dengan persekutuan komanditer lainnya. Jika di dalam ketentuan tersebut adanya kata-kata "bukan sekutu pengurus", maka ketentuan itu berlaku untuk persekutuan komanditer. Persekutuan komanditer mengenal dua macam sekutu, yakni sekutu pengurus dan sekutu komanditer.

Dengan demikian penulis merumuskan bahwa organisasi perusahaan adalah suatu unit organisasi usaha yang memproduksi barang dan jasa untuk memenuhi kebutuhan masyarakat dengan tujuan untuk medapat- kan keuntungan. Sedangkan perusahaan dipandang dari sisi hukum adalah suatu kegiatan usaha yang dijalankan secara terusmenerus, tidak terputus-putus dan terangterangan yang bergerak keluar dengan tujuan untuk mendapatkan keuntungan.

\section{Jenis-jenis Organisasi Perusahaan da- lam Sistem Hukum Indonesia}

Secara teoritis, oraganisasi perusahaan yang berskala nasional maupun iternasional dapat dikelompokkan menjadi 3 jenis yaitu: Pertama, perusahaan industri yaitu perusahaan yang memproduksi bahan mentah menjadi barang setengan jadi dan barang jadi; Kedua, perusahaan dagang yaitu perusahaan yang bergerak dalam bidang perdagangan tanpa mengolahnya terlebih dahulu; dan Ketiga, perusahaan jasa yaitu perusahaan yang bergerak dibidang penjualan jasa. ${ }^{7}$

Menurut Siti Hidayah, ${ }^{8}$ organisasi perusahaan berbadan hukum memiliki ciri-ciri, antara lain: 1) pendirianya disahkan oleh menteri kehakiman dan keuangan; 2) memiliki anggaran dasar perusahaan; 3) memiliki anggota sekutu yang cukup; dan 4) memiliki struktur modal (statute, ditetapkan dan disetor. Sedangkan ciri-ciri perusahaan yang belum/tidak berbadan hukum adalah: 1) pendiriannya hanya dilakukan di depan notaris; 2) disahkan oleh Pengadilan Negeri setempat; 3) dijalankan atas nama bersama; 4) tidak memiliki anggaran dasar dan anggaran rumah tangga; dan 5) adanya suatu pertanggungjawaban bersifat pribadi dan publik untuk keseluruhan kegiatan usaha.

Penulis mengidentidikasi bahwa yang termasuk ke dalam perusahaan berbadan hukum adalah Perseoran Terbatas, Firma, Koperasi, Yayasan, BUMN, dan sebagainya

7 Lihat Siti Hidayah, "Ciri-ciri Organisasi Perusahaan", artikel dalam http://accountingiismylife. blogspot.com/2013/07/organisasi-perusahaan.html diakses tanggal 22 Januari 2014.

${ }^{8}$ R.T. Sutantya R. Handhikusuma dan Sumantoro, Pengertian Pokok Hukum Perusahaan Bentuk-Bentuk Perusahaan yang Berlaku di Indonesia (Jakarta: Rajawali Pers, 1991), hlm 23. 
yang diatur dalam peraturan perundangundangan. Kini hukum di Indonesia mengatur hal tersebut Undang-Undang Nomor 3 Tahun 1992 tentang Wajib Daftar Perusahaan, dan Undang-Undang Nomor 8 Tahun 1997 tentang Dokumen Perusahaan. ${ }^{9}$

Sistem perekonomian suatu negara digerakan oleh pelaku-pelaku kegiatan ekonomi yang menjalankan kegiatan produksi, distribusi, dan konsumsi. Kegiatan produksi umumnya dilakukan oleh perusahaan dan badan usaha yang menjalankan fungsi produksi untuk memenuhi kebutuhan baik berupa barang maupun jasa. Oleh karena itu, setiap organisasi perusahan terkait dengan beberapa ketentuan yang harus ditaati dan dipatuhi. Misalnya status badan hukum, ciri, operasional, dan kewajiban hukum dari organisasi perusahaan itu sendiri. ${ }^{10}$

\section{Badan Hukum}

Badan hukum adalah suatu realitas (bukan fiksi) dan berupa suatu konstruksi hukum. Dikatakan bahwa badan hukum adalah subyek hukum, sama dengan manusia, dengan perbedaan bahwa badan hukum mempunyai hak dan kewajiban yang diberikan oleh undang-undang untuk mengabdi pada kehidupan hukum manusia. Manusia sendiri mempunyai hak dan kewajiban berdasarkan asas-asas kesusilaan dan kemasyarakatan, dan karena itu dikenal adanya hak asasi manusia.

Dalam kenyataan perlu diketahui bahwa misalnya badan hukum PT berbuat atau bertindak melalui manusia (yang dikenal dalam Undang-Undang Perseroan Terbatas Nomor

9 Rudhi Prasteya, Matschap, Firma, dan Persekutuan Komanditer (Bandung: Citra Aditya Bakti, 3002), hlm 4-5.

10 Lihat penjelasan Riki Priadi, Jenis-jenis Perusahaan Berbadan Hukum di Indonesia, aertikel dalam

http://ilmuisteman.blogspot.com/2011/o9/organisasiper usahaan-yang-berbadan.html, lihat pula dalam http://emperordeva.wordpress.com/about/makalahtentang-perseroan-terbatas-untuk-mahasiswa-unhi/, http://kholil.staff.uns.ac.id/files/2010/03/hukum-pt-uu40_2007_versi-akhir.ppt, dan http://metamuetz. blogspot.com/2011/11/makalah-koperasi.html dan http://id.wikipedia.org/wiki/Koperasi diakses tanggal 22 Januari 2014
1 Tahun 1995 sebagai Direksi). Dalam Pasal 82 dikatakan bahwa direksi bertanggungjawab penuh atas pengurusan perseroan untuk kepentingan dan tujuan perseroan serta mewakili baik didalam maupun diluar pengadilan”. Dengan demikian antara Direksi dan korporasi ada hubungan istimewa yang dinamakan "fiduciary relationship" (hubungan kepercayaan), yang melahirkan "fiduciary duties" bagi setiap anggota direksi.

\section{Perusahaan}

Menurut rumusan Pasal 1 huruf (b) Undang-Undang Nomor 3 Tahun 1982 tentang Wajib Daftar Perusahaan, dikemukakan bahwa: "Perusahaan adalah setiap bentuk usaha yang menjalankan setiap jenis usaha yang bersifat tetap dan terus-menerus dan yang didirikan, bekerja serta berkedudukan dalam wilayah Negara Republik Indonesia, untuk tujuan memperoleh keuntungan dan atau laba". Berdasarkan ketentuan pasal tersebut, maka dalam definisi perusahaan adalah Bentuk usaha yang berupa organisasi atau badan usaha yang didirikan, bekerja, dan berkedudukan dalam wilayah negara Indonesia untuk memperoleh keuntungan.

Hukum Perusahaan merupakan pengkhususan dari beberapa bab dalam KUH Perdata dan KUHD (Kodifikasi) ditambah dengan peraturan perundangan lain yang mengatur tentang perusahaan (hukum tertulis yang belum dikodifikasi). Sesuai dengan perkembangan dunia perdagangan dewasa ini, maka sebagian dari hukum perusahaan merupakan peraturan-peraturan hukum yang masih baru. Apabila hukum dagang (KUHD) merupakan hukum khusus (lex specialis) terhadap hukum perdata (KUH Perdata) yang bersifat lex generalis, demikian pula hukum perusahaan merupakan hukum khusus terhadap hukum dagang.

Ciri-ciri dari perusahaan berbadan hukum adalah: a) terus-menerus; b) mendapatkan penghasilan; dan c) mengadakan perjanjian perdagangan mempunyai akta pendirian perusahaan yang dibuat oleh notaris dan telah memperoleh pengesahan dari menteri hukum dan hamyang pasti perusahan yang 
memiliki izin yg sah,dan membayar pajak tiap tahun.

Dalam hal ini ada beberapa jenis perusahaan dalam yang diatur tata peraturan perundang-undangan badan hukum perusahaan di Indonesia, yaitu: ${ }^{11}$

\section{a) Perusahaan Terbatas (PT)}

Istilah Perseroan Terbatas (PT) dulunya dikenal dengan istilah Naamloze Vennootschap (NV). Istilah lainnya Corporate Limited (Co. Ltd.), Serikat Dagang Benhard (SDN BHD). Pengertian Perseroan Terbatas terdiri dari dua kata, yakni "perseroan" dan "terbatas". Perseroan merujuk kepada modal PT yang terdiri dari sero-sero atau sahamsaham. Adapun kata terbatas merujuk kepada pemegang yang luasnya hanya sebatas pada nilai nominal semua saham yang dimilikinya. Berdasarkan Pasal 1 UUPT Nomor 40 Tahun 2007 pengertian Perseroan Terbatas (Perseroan) adalah badan hukum yang merupakan persekutuan modal, didirikan berdasarkan perjanjian, melakukan kegiatan usaha dengan modal dasar yang seluruhnya terbagi dalam saham, dan memenuhi persyaratan yang ditetapkan dalam undang-undang ini serta peraturan pelaksanaannya.

Secara khusus badan usaha Perseroan Terbatas diatur dalam Undang-Undang Nomor 40 Tahun 2007 tentang Perseroan Terbatas (UUPT), yang secara efektif berlaku sejak tanggal 16 Agustus 2007. Sebelum UUPT 2007, berlaku UUPT Nomor 1 Tahun 1995 yg diberlakukan sejak 7 Maret 1996 (satu tahun setelah diundangkan) s.d. 15 Agustus 2007, UUPT Nomor 1 Tahun 1995 tersebut sebagai pengganti ketentuan tentang Perseroan Terbatas yang diatur dalam KUHD Pasal 36 sampai dengan Pasal 56, dan segala perubahannya (terakhir dengan UndangUndang Nomor 4 Tahun 1971 yang mengubah sistem hak suara para pemegang saham yang diatur dalam Pasal 54 KUHD dan Ordonansi Perseroan Indonesia atas saham Ordonantie op de Indonesische Maatschap-

11 M. Natzir Said, Hukum Perusahaan di Indonesia, Jilid I (Perorangan) (Bandung: Alumni, 1987, hlm 58. pij op Aandeelen (IMA)- diundangkan dalam Staatsblad 1939 Nomor 569 jo. 717.

Untuk mendirikan PT, harus dengan menggunakan akta resmi (akta yang dibuat oleh notaris) yang di dalamnya dicantumkan nama lain dari Perseroan Terbatas, modal, bidang usaha, alamat Perusahaan, dan lainlain. Akta ini harus disahkan oleh menteri Hukum dan Hak Asasi Manusia Republik Indonesia (dahulu Menteri Kehakiman). Untuk mendapat izin dari menteri kehakiman, harus memenuhi syarat sebagai berikut: ${ }^{12}$

1) Perseroan terbatas tidak bertentangan dengan ketertiban umum dan kesusilaan;

2) Akta pendirian memenuhi syarat yang ditetapkan Undang-Undang; dan

3) Paling sedikit modal yang ditempatkan dan disetor adalah $25 \%$ dari modal dasar. (sesuai dengan Undang-Undang Nomor 1 Tahun 1995 dan Undang-Undang Nomor 40 Tahun 2007, keduanya tentang Perseroan Terbatas).

Setelah mendapat pengesahan, dahulu sebelum adanya Undang-Undang tentang Perseroan Terbatas (Undang-Undang Nomor 1 tahun 1995) Perseroan Terbatas harus didaftarkan ke Pengadilan Negeri setempat, tetapi setelah berlakunya Undang-Undang Nomor 1 Tahun 1995 tersebut, maka akta pendirian tersebut harus didaftarkan ke Kantor Pendaftaran Perusahaan (sesuai UndangUndang Wajib Daftar Perusahaan tahun 1982) (dengan kata lain tidak perlu lagi didaftarkan ke Pengadilan negeri, dan perkembangan tetapi selanjutnya sesuai UndangUndang Nomor 40 Tahun 2007, kewajiban pendaftaran di Kantor Pendaftaran Perusahaan tersebut ditiadakan juga. Sedangkan tahapan pengumuman dalam Berita Negara Republik Indonesia (BNRI) tetap berlaku, hanya yang pada saat Undang-Undang Nomor 1 Tahun 1995 berlaku pengumuman tersebut merupakan kewajiban Direksi PT yang bersangkutan tetapi sesuai dengan UndangUndang Nomor 40 Tahun 2007 yang diubah

12 H.M.N. Purwosutjipto, Pengertian Pokok Hukum Dagang Indonesia, Jilid I (Jakarta, Djambatan, 1981), hlm. 9. 
menjadi merupakan kewenangan/kewajiban Menteri Hukum dan HAM.

Setelah tahap tersebut dilalui maka perseroan telah sah sebagai badan hukum dan perseroan terbatas menjadi dirinya sendiri serta dapat melakukan perjanjian-perjanjian dan kekayaan perseroan terpisah dari kekayaan pemiliknya. Modal dasar perseroan adalah jumlah modal yang dicantumkan dalam akta pendirian sampai jumlah maksimal bila seluruh Saham dikeluarkan. Selain modal dasar, dalam Perseroan Terbatas juga terdapat modal yang ditempatkan, modal yang disetorkan dan modal bayar. Modal yang ditempatkan merupakan jumlah yang disanggupi untuk dimasukkan, yang pada waktu pendiriannya merupakan jumlah yang disertakan oleh para persero Pendiri. Modal yang disetor merupakan modal yang dimasukkan dalam perusahaan. Modal bayar merupakan modal yang diwujudkan dalam jumlah Uang.

Jenis-jenis PT dapat dibagi ke dalam beberapa bentuk: ${ }^{3}$

1) Perseroan terbatas terbuka adalah perseroan terbatas yang menjual sahamnya kepada masyarakat melalui pasar modal (go public). Jadi sahamnya ditawarkan kepada umum, diperjualbelikan melalui bursa saham dan setiap orang berhak untuk membeli saham perusahaan tersebut;

2) Perseroan Terbatas tertutup adalah perseroan terbatas yang modalnya berasal dari kalangan tertentu misalnya pemegang sahamnya hanya dari kerabat dan keluarga saja atau kalangan terbatas dan tidak dijual kepada umum; dan

3) Perseroan terbatas kosong adalah perseroan terbatas yang sudah tidak aktif menjalankan usahanya dan hanya tinggal nama saja.

Dalam Perseroan Terbatas selain kekayaan perusahaan dan kekayaan pemilik modal terpisah juga ada pemisahan antara pemilik perusahaan dan pengelola perusahaan. Pengelolaan perusahaan dapat diserahkan

13 Imran Ahsan Khan Nyazee, Islamic law of Business Organization, Partnership, (Kuala Lumpur, The Other Press, 1997), hlm 13. kepada tenaga-tenaga ahli dalam bidangnya profesional. Struktur organisasi Perseroan Terbatas terdiri dari pemegang saham, direksi, dan komisaris. ${ }^{14}$

Dalam PT, para pemegang saham melimpahkan wewenangnya kepada direksi untuk menjalankan dan mengembangkan perusahaan sesuai dengan tujuan dan bidang usaha perusahaan. Dalam kaitan dengan tugas tersebut, direksi berwenang untuk mewakili perusahaan, mengadakan perjanjian dan kontrak, dan sebagainya. Apabila terjadi kerugian yang amat besar (di atas 50\%) maka direksi harus melaporkannya ke para pemegang saham dan pihak ketiga, untuk kemudian dirapatkan.

Komisaris memiliki Fungsi sebagai pengawas kinerja jajaran direksi perusahaan. Komisaris bisa memeriksa pembukuan, menegur direksi, memberi petunjuk, bahkan bila perlu memberhentikan direksi dengan menyelenggarakan RUPS (Rapat Umum Pemegang Saham) untuk mengambil keputusan apakah direksi akan diberhentikan atau tidak. Dalam RUPS, semua pemegang saham sebesar/sekecil apapun sahamnya memiliki hak untuk mengeluarkan suaranya.

Dalam RUPS sendiri dibahas masalahmasalah yang berkaitan dengan evaluasi kinerja dan kebijakan perusahaan yang harus dilaksanakan segera. Bila pemegang saham berhalangan, dia bisa melempar Suara miliknya ke pemegang lain yang disebut Proxy Hasil RUPS biasanya dilimpahkan ke komisaris untuk diteruskan ke direksi untuk dijalankan.

Isi dalam RUPS mencakup atas:

1) Menentukan direksi dan pengangkatan komisaris;

2) Memberhentikan direksi atau komisaris;

3) Menetapkan besar gaji direksi dan komisaris;

4) Mengevaluasi kinerja perusahaan;

5) Memutuskan rencana penambahan/pengurangan saham perusahaan;

6) Menentukan kebijakan perusahaan; dan

14 Rudhi Prasetya, Kedudukan Mandiri Perseroan Terbatas (Bandung: Citra Aditya Bakti, 1995), hlm. 46. 
7) Mengumumkan pembagian laba.

Keuntungan membentuk perusahaan

Perseroan Terbatas adalah:

1) Kewajiban terbatas. Tidak seperti partnership, pemegang saham sebuah perusahaan tidak memiliki kewajiban untuk obligasi dan hutang perusahaan. Akibatnya kehilangan potensial yang "terbatas" tidak dapat melebihi dari jumlah yang mereka bayarkan terhadap saham. Tidak hanya ini mengijinkan perusahaan untuk melaksanakan dalam usaha yang berisiko, tetapi kewajiban terbatas juga membentuk dasar untuk perdagangan di saham perusahaan;

2) Masa hidup abadi. Aset dan struktur perusahaan dapat melewati masa hidup dari pemegang sahamnya, pejabat atau direktur. Ini menyebabkan stabilitas modal (ekonomi), yang dapat menjadi Investasi dalam proyek yang lebih besar dan dalam jangka waktu yang lebih panjang daripada aset perusahaan tetap dapat menjadi subyek disolusi dan penyebaran. Kelebihan ini juga sangat penting dalam periode pertengahan, ketika tanah disumbangkan kepada Gereja (sebuah perusahaan) yang tidak akan mengumpulkan biaya Feudal yang seorang tuan tanah dapat mengklaim ketika pemilik tanah meninggal. Untuk hal ini, lihat Statute of Mortmain; dan

3) Efisiensi manajemen. Manajemen dan spesialisasi memungkinkan pengelolaan modal yang efisien sehingga memungkinkan untuk melakukan ekspansi. Dan dengan menempatkan orang yang tepat, efisiensi maksimum dari modal yang ada. Dan juga adanya pemisahan antara pengelola dan pemilik perusahaan, sehingga terlihat tugas pokok dan fungsi masingmasing.

Kelemahan Perseroan Terbatas adalah kerumitan perizinan dan organisasi. Untuk mendirikan sebuah PT tidaklah mudah. Selain biayanya yang tidak sedikit, PT juga membutuhkan akta notaris dan izin khusus untuk usaha tertentu. Lalu dengan besarnya peru- sahaan tersebut, biaya pengorganisasian akan keluar sangat besar. Belum lagi kerumitan dan kendala yang terjadi dalam tingkat personel. Hubungan antar perorangan juga lebih formal dan berkesan kaku.

\section{b) Koperasi}

Koperasi adalah badan usaha yang beranggotakan orang-orang atau badan hukum koperasi dengan melandaskan kegiatannya berdasarkan prinsip koperasi sekaligus sebagai gerakan ekonomi rakyat yang berdasarkan asas kekeluargaan. Koperasi bertujuan untuk menyejahterakan anggotanya. Berdasarkan pengertian tersebut, yang dapat menjadi anggota koperasi yaitu: 1) perorangan, yaitu orang yang secara sukarela menjadi anggota koperasi; dan 2) badan hukum koperasi, yaitu suatu koperasi yang menjadi anggota koperasi yang memiliki lingkup lebih luas.

Landasan, asas, dan tujuan koperasi Indonesia sebagaimana diatur dalam Undang-Undang Nomor 25 Tahun 1992 tentang Perkoperasian, dijelaskan pada bab II dalam dua pasal. Landasan dan asas koperasi dijelaskan dalam pasal 2 yaitu tujuan koperasi dijelaskan dalam pasal 3 berikut kutipan bunyi lengkap pasal dimaksud. Sedangkan menurut Pasal 2, koperasi berlandaskan Pancasila dan Undang-Undang Dasar 1945 atas asas kekeluargaan. Adapun menurut Pasal 3, koperasi bertujuan memajukan kesejahteraan anggota pada khususnya dan masyarakat pada umumnya serta ikut membangun tatanan perkeonomian nasional dalam rangka mewujudkan masyarakat yang maju, adil, dan Undang-Undang Dasar 1945.

Prinsip koperasi adalah suatu sistem ideide abstrak yang merupakan petunjuk untuk membangun koperasi yang efektif dan tahan lama. Prinsip koperasi terbaru yang dikembangkan International Cooperative Alliance (Federasi Koperasi non-pemerintah Internasional) adalah: ${ }^{15}$

1) Keanggotaan yang bersifat terbuka dan sukarela;

\footnotetext{
${ }^{15} \mathrm{lbid}$.
} 
2) Pengelolaan yang demokratis;

3) Partisipasi anggota dalam ekonomi;

4) Kebebasan dan otonomi; dan

5) Pengembangan pendidikan, pelatihan, dan informasi.

Di Indonesia telah dibuat UndangUndang Nomor 25 tahun 1992 tentang Perkoperasian, yang mana prinsip koperasi menurut Undang-Undang Nomor 25 tahun 1992 adalah: ${ }^{16}$

1) Keanggotaan bersifat sukarela dan terbuka;

2) Pengelolaan dilakukan secara demokrasi;

3) Pembagian SHU dilakukan secara adil sesuai dengan jasa usaha masing-masing anggota;

4) Pemberian balas jasa yang terbatas terhadap modal;

5) Kemandirian;

6) Pendidikan perkoperasian; dan

7) Kerjasama antar koperasi.

Bentuk dan jenis koperasi dibagi menurut pembelian/pengadaan/konsumsi adalah koperasi perdagangan yang menyelenggarakan fungsi pembelian atau pengadaan barang dan jasa untuk memenuhi kebutuhan anggota sebagai konsumen akhir. Di sini anggota berperan sebagai pemilik dan pembeli atau konsumen bagi koperasinya. Koperasi penjualan/pemasaran adalah koperasi yang menyelenggarakan. Fungsi distribusi barang atau jasa yang dihasilkan oleh anggotanya agar sampai di tangan konsumen. Di sini anggota berperan sebagai pemilik dan pemasok barang atau jasa kepada koperasinya. ${ }^{17}$

Koperasi produksi adalah koperasi yang menghasilkan barang dan jasa, di mana anggotanya bekerja sebagai pegawai atau karyawan koperasi. Di sini anggota berperan sebagai pemilik dan pekerja koperasi. Sedangkan koperasi jasa adalah koperasi yang menyelenggarakan pelayanan jasa yang dibutuhkan oleh anggota, misalnya: simpan pinjam, asuransi, angkutan, dan sebagainya. Di sini anggota berperan sebagai pemilik dan pengguna layanan jasa koperasi. Apabila ko- perasi menyelenggarakan satu fungsi disebut koperasi tunggal usaha (single purpose cooperative), sedangkan koperasi yang menyelenggarakan lebih dari satu fungsi disebut koperasi serba usaha (multi purpose cooperative).

Jenis koperasi berdasarkan tingkat dan luas daerah kerja, misalnya koperasi primer yaitu koperasi yang yang minimal memiliki anggota sebanyak 20 orang perseorangan. Koperasi Sekunder yaitu koperasi yang terdiri dari gabungan badan-badan koperasi serta memiliki cakupan daerah kerja yang luas dibandingkan dengan koperasi primer. Koperasi sekunder dapat dibagi menjadi: 1) koperasi pusat adalah koperasi yang beranggotakan paling sedikit 5 koperasi primer; 2) gabungan koperasi adalah koperasi yang anggotanya minimal 3 koperasi pusat; dan 3) induk koperasi adalah koperasi yang minimum anggotanya adalah 3 gabungan koperasi. $^{18}$

Jenis koperasi menurut status keanggotaannya mencakup atas koperasi produsen adalah koperasi yang anggotanya para produsen barang/jasa dan memiliki rumah tangga usaha. Sedangkan koperasi konsumen adalah koperasi yang anggotanya para konsumen akhir atau pemakai barang/jasa yang ditawarkan para pemasok di pasar. Kedudukan anggota di dalam koperasi dapat berada dalam salah satu status atau keduanya. Dengan demikian pengelompokkan koperasi menurut status anggotanya berkaitan erat dengan pengelompokan koperasi menurut fungsinya.

Keunggulan koperasi adalah adanya kemungkinan koperasi untuk memperoleh keunggulan komparatif dari perusahaan lain cukup besar mengingat koperasi mempunyai potensi kelebihan antara lain pada skala ekonomi, aktivitas yang nyata, faktor-faktor precuniary, dan lain-lain. Selain itu, kewirausahaan koperasi menjadi suatu sikap mental positif dalam berusaha secara koperatif, dengan mengambil prakarsa inovatif serta

\footnotetext{
${ }^{16}$ Ibid.

${ }^{17}$ Ibid.
} 
keberanian mengambil risiko dan berpegang teguh pada prinsip identitas koperasi, dalam mewujudkan terpenuhinya kebutuhan nyata serta peningkatan kesejahteraan bersama. ${ }^{19}$

Dari definisi tersebut, maka dapat dikemukakan bahwa kewirausahaan koperasi merupakan sikap mental positif dalam berusaha secara koperatif. Tugas utama wirakop adalah mengambil prakarsa inovatif, artinya berusaha mencari, menemukan, dan memanfaatkan peluang yang ada demi kepentingan bersama. Kewirausahaan dalam koperasi dapat dilakukan oleh anggota, manajer birokrat yang berperan dalam pembangunan koperasi dan katalis, yaitu orang yang peduli terhadap pengembangan koperasi.

Demikian halnya dengan keberadaan pengurus koperasi dipilih dari kalangan dan oleh anggota dalam suatu rapat anggota. Ada kalanya rapat anggota tersebut tidak berhasil memilih seluruh anggota pengurus dari kalangan anggota sendiri. Hal demikian umpamanya terjadi jika calon-calon yang berasal dari kalangan-kalangan anggota sendiri tidak memiliki kesanggupan yang diperlukan untuk memimpin koperasi yang bersangkutan, sedangkan ternyata bahwa yang dapat memenuhi syarat-syarat ialah mereka yang bukan anggota atau belum anggota koperasi (mungkin sudah turut dilayani oleh koperasi akan tetapi resminya belum meminta menjadi anggota).

Keberaan koperasi di Indonesia menurut Undang-Undang Nomor 7 Tahun 1992, didefinisikan sebagai badan usaha yang beranggotakan orang-seorang atau badan hukum koperasi dengan melandaskan kegiatannya berdasarkan prinsip-prinsip koperasi sekaligus sebagai gerakan ekonomi rakyat yang berdasar atas asas kekeluargaan. Di Indonesia, prinsip koperasi telah dicantumkan dalam Undang-Undang Nomor 12 Tahun 1967 dan Undang-Undang Nomor 25 Tahun 1992. Prinsip koperasi di Indonesia kurang lebih sama dengan prinsip yang diakui dunia internasional dengan adanya sedikit perbedaan,

\footnotetext{
${ }^{19} \mathrm{lbid}$.
}

yaitu adanya penjelasan mengenai SHU (Sisa Hasil Usaha).

Selain itu dikenal pula bentuk-bentuk organisasi bisnis antara lain: 1) perusahaan perseorangan; 2) persekutuan firma; 3) perseroan komanditer (Commanditer Vennootschap/CV); 4) Perseroan Terbatas; 5) Koperasi; 6) Yayasan; dan 7) BUMN. Beberapa pertimbangan yang perlu dilakukan dalam memilih bentuk perusahaan, antara lain: 1) jenis usaha yang dijalankan (perdagangan, industri, dan sebagainya); 2) ruang lingkup usaha; 3) pihak-pihak yang terlibat dalam kegiatan usaha; 4) besarnya risiko pemilikan; 5) batas-batas pertanggungjawaban terhadap utang-utang perusahaan; 7) besarnya investasi yang ditanamkan; 7) cara pembagian keuntungan; 8) jangka waktu berdirinya perusahaan; dan 9) peraturan-peraturan pemerintahan tentang perusahaan.

Menurut Undang-Undang Nomor 3 Tahun 1982 tentang Wajib Daftar Perusahaan Pasal 1 huruf (b) yang dimaksud dengan perusahaan adalah setiap bentuk usaha yang menjalankan setiap jenis usaha yang bersifat tetap dan terus menerus yang didirikan, bekerja, serta berkedudukan dalam wilayah negara Indonesia dengan tujuan memperoleh keuntungan dan atau laba.

Dengan demikian dapat dirumuskan bahwa perusahaan badan hukum adalah organisasi yang diwujudkan/diciptakan oleh hukum sebagai pembawa hak dan kewajiban seperti halnya manusia. Karena itu badan hukum dapat mempunyai kekayaan sendiri, utang piutang sendiri, dapat digugat dan menggugat. Badan hukum dapat melakukan perbuatan hukum setelah akta pendirian badan hukum tersebut mendapat pengesahan dari pemerintah/Departemen Kehakiman. Adapun yang termasuk ke dalam kelompok perusahaan berbadan hukum adalah Perseoran Terbatas (PT), koperasi, yayasan, BUMN, dan sebagainya sebagaimana diatur dalam peraturan perundang-undangan.

\section{Penutup}

Secara historis, hukum dagang adalah hukum perdata khusus bagi pedagang. Me- 
nurut Pasal 2 KUHD (sudah dicabut), pedagang adalah mereka yang melakukan perbuatan perniagaan sebagai pekerjaannya sehari-hari. Kemudian oleh Pasal 3 KUHD (lama) disebutkan lagi bahwa perbuatan perniagaan pada umumnya adalah perbuatan pembelian barang-barang untuk dijual kembali. Dalam KUHD diatur bahwa perbuatan perniagaan hanya perbuatan pembelian saja, sedangkan perbuatan penjualan tidak termasuk di dalamnya karena penjualan merupakan tujuan pembelian itu; dan pengertian barang di sini berarti barang bergerak. Jadi, tidak termasuk barang tetap.

Dalam KUHD juga diatur bahwa kegiatan yang termasuk dalam kategori perbuatan bisnis adalah perbuatan-perbuatan yang timbul dari kewajiban-kewajiban menjalankan kapal untuk melayari laut, kewajibankewajiban mengenai tubrukan kapal, tolongmenolong dan menyimpan barang-barang di laut yang berasal dari kapal karam atau terdampar, begitu pula penemuan barang-barang di laut, pembuangan barang-barang di laut ketika terjadi avarai (avarij).

Karena perusahaan diatur dalam undang-undang maka badan hukum disebut sebagai organisasi yang diwujudkan/diciptakan oleh hukum sebagai pembawa hak dan kewajiban seperti halnya manusia. Karena itu badan hukum dapat mempunyai kekayaan sendiri, utang piutang sendiri, dapat digugat dan menggugat. Badan hukum juga dapat melakukan perbuatan hukum setelah akta pendirian badan hukum tersebut mendapat pengesahan dari pemerintah/Departemen Kehakiman. Yang termasuk ke dalam perusahaan berbadan hukum adalah Perseoran Terbatas, firma, koperasi, yayasan, BUMN, dan sebagainya yang diatur dalam peraturan perundang-undangan. Kini hukum di Indonesia mengatur hal tersebut UndangUndang Nomor 3 Tahun 1992 tentang Wajib Daftar Perusahaan, dan Undang-Undang Nomor 8 Tahun 1997 tentang Dokumen Perusahaan.

\section{Daftar Pustaka}

Editor, http://emperordeva.wordpress.com/abut-makalah-tentang-perseroan-terbatas-untuk-mahasiswa-unhi/, diakses tanggal 22 Januari 2014.

Editor, http://kholil.staff.uns.ac.id/files/2010/03/hukum-pt-uu-40_2007_versi-akhir.ppt, diakses tanggal 22 Januari 2014.

Editor, http://metamuetz.blogspot.com/2011/11/makalah-koperasi.html, diakses tanggal 22 Januari 2014.

Editor,http://id.wikipedia.org/wiki/Koperasi diakses tanggal 22 Januari 2014.

Harianja, Marihot Tua Efendi. 2006. Perilaku Organisasi (Memahami dan Mengelola Perilaku Dalam Organisasi. Bandung: UNPAR PRESS.

Hidayah, Siti. 2013. "Ciri-ciri Organisasi Perusahaan", artikel dalam http://accountingiismylife. blogspot.com/2013/07/organisasi-perusahaan.html, diakses tanggal 22 Januari 2014.

Nyazee, Imran Ahsan Khan. 1997. Islamic law of Business Organization, Partnership. Kuala Lumpur: The Other Press.

Prasteya, Rudhi. 2002. Matschap, Firma, dan Persekutuan Komanditer. Bandung: Citra Aditya Bakti.

Priadi, Riki. 2011. "Jenis-jenis Perusahaan Berbadan Hukum di Indonesia”. artikel dalam http://ilmuisteman.blogspot.com/2011/o9/organisasiperusahaan-yang-berbadan.html, diakses tanggal 22 Januari 2014.

Purwosutjipto, H.M.N. 1981. Pengertian Pokok Hukum Dagang Indonesia. Jakarta: Djambatan.

Rivai. 2006. Kepemimpinan dan Perilaku Organisasi. Jakarta: Raja Grafindo Persada.

Said, M. Natzir. 1987. Hukum Perusahaan di Indonesia. Bandung: Alumni.

Siagian, Sondang P. 1993. Analisis serta Perumusan Kebijaksanaan dan Strategi Organisasi. Jakarta: Haji Masagung.

Suryono, Joko. 2013. "Ciri-ciri Organisasi Perusahaan, artikel dalam http://www.trainingcenter. co.id/aspek-hukum-orga- 
nisasi-perusahaan, diakses tanggal 22 Januari 2014.

Sutantya, R. T. dan Sumantoro. 1991. Pengertian Pokok Hukum Perusahaan
Bentuk-Bentuk Perusahaan yang Berlaku di Indonesia. Jakarta: Rajawali Pers.

Tim Fokus Group. 2012. Kitab Undang-Undang Hukum Dagang. Jakarta: Fokus Group Press. 